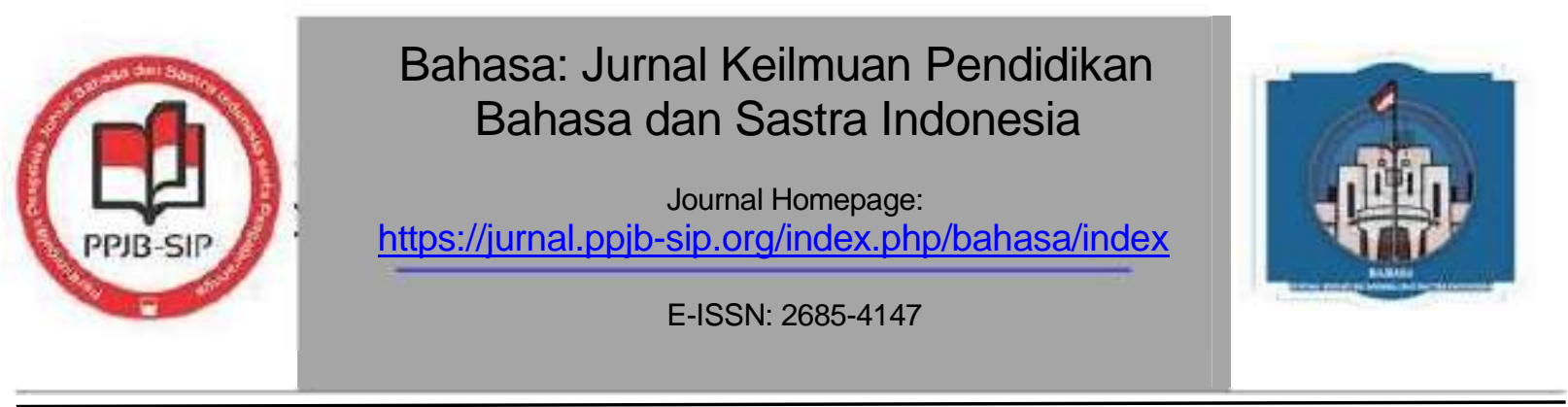

\title{
THE CORRELATION BETWEEN STUDENTS' ARTIFICIAL INTELLIGENCE AND THEIR ENGLISH READING SKILLS ACHIEVEMENT
}

\section{HUBUNGAN ANTARA KECERDASAN BUATAN SISWA DAN PENCAPAIAN KETERAMPILAN MEMBACA BAHASA INGGRIS MEREKA}

\author{
Sri Lestari ${ }^{1}$, Wahyuningsih Usadiati ${ }^{2}$, Misrita $^{3}$ \\ ${ }_{1,2,3}^{1}$ University of Palangka Raya \\ Email: ${ }^{1}$ lestariami86@gmail.com, ${ }^{2}$ wahyu.usadiati@edu.upr.ac.id, ${ }^{3}$ ritaqal@yahoo.com
}

\begin{abstract}
:
Artificial intelligence is intelligence that is added to a system that can be regulated in a scientific context or it can be called artificial intelligence. Students usually use the media to improve their English skills with a variety of mobile applications in mastering effective and critical English in order to gain a better understanding of English reading skills. The aims of this study are to know the correlation between students' artificial intelligence and their English reading skills achievement in the second semester class of the English Study Program at the Islamic University of Kalimantan, Muhammad Arsyad Al Banjari Banjarmasin. In this research, the researcher uses quantitative approach by correlation technique. To measure students' artificial intelligence, the author shares several questions related to the topic by using google form. The study population is a total of 30 students consists of male and female students in a class. After doing research, it was found that the correlation between students' artificial intelligence and English reading skill achievement was quite high. This is indicated by the results of the research (0.67), where this value shows that there is a significant relationship between the variable $x$ (students' artificial intelligence) and the variable $y$ (learning outcomes of students' Reading achievement). As for the results showing that the mobile application helps improve students' reading skills in English.
\end{abstract}

Keywords: Artificial Intelligence, English Reading Skill Achievement.

\begin{abstract}
Abstrak:
Kecerdasan buatan adalah kecerdasan yang ditambahkan pada suatu sistem yang dapat diatur dalam konteks ilmiah atau bisa disebut kecerdasan buatan. Siswa biasanya menggunakan media untuk meningkatkan kemampuan bahasa Inggris mereka dengan berbagai aplikasi seluler dalam menguasai bahasa Inggris yang efektif dan kritis untuk mendapatkan pemahaman yang lebih baik tentang keterampilan membaca bahasa Inggris. Tujuan dari penelitian ini adalah untuk mengetahui hubungan antara kecerdasan buatan mahasiswa dengan pencapaian kemampuan membaca bahasa Inggris pada semester dua Program Studi Bahasa Inggris di Universitas Islam Kalimantan, Muhammad Arsyad Al Banjari Banjarmasin. Dalam penelitian ini, peneliti menggunakan pendekatan kuantitatif dengan teknik korelasional. Untuk mengukur kecerdasan buatan siswa, penulis membagikan beberapa pertanyaan terkait topik dengan menggunakan google form. Populasi penelitian ini berjumlah 30 mahasiswa yang terdiri dari laki-laki dan perempuan dalam satu kelas.
\end{abstract}

Received 22-10-2021, Accepted 23-11-2021

https://doi.org/10.26499/bahasa.v3i2.110

Published By: Perkumpulan Pengelola Jurnal Bahasa dan Sastra Indonesia (PPJB-SIP) 


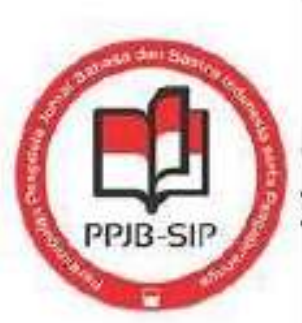

\section{Bahasa: Jurnal Keilmuan Pendidikan Bahasa dan Sastra Indonesia}

Journal Homepage:

https://jurnal.ppib-sip.org/index.php/bahasa/index

E-ISSN: $2685-4147$

Setelah dilakukan penelitian, ditemukan bahwa hubungan antara kecerdasan buatan siswa dengan pencapaian keterampilan membaca bahasa Inggris cukup tinggi. Hal ini ditunjukkan oleh hasil penelitian $(0,67)$, dimana nilai ini menunjukkan bahwa terdapat hubungan yang signifikan antara variabel $x$ (kecerdasan buatan siswa) dan variabel y (hasil belajar terhadap prestasi membaca siswa). Adapun hasil yang menunjukkan bahwa aplikasi mobile membantu meningkatkan kemampuan membaca siswa dalam bahasa Inggris.

Kata kunci: Kecerdasan Buatan, Pencapaian Keterampilan Membaca Bahasa Inggris.

\section{INTRODUCTION}

Language is primarily a way of communication. Communication itself almost always occurs within some kind of social context. Language is integrally entangled with ideas about who we are on both personal and social levels. When people use language, they convey their individual thoughts as well as the cultural beliefs and practices of the communities in which they are surrounded by family, social teams, and alternative associations (Kuiper, Allan, Kuiper, \& Allan, 2017). In addition, language is a gift of God that distinguishes humans from animals. Language will mean a collection of words arranged in sentences, where each word has its own meaning (Haerazi et.al., 2018).

English is also a language that offers the expression of the thoughts and feelings of a group (Haerazi and Irawan, 2019). Language is actually a talent and not a content-based subject like science, social science, commerce, mathematics, and so on which aim to provide information and fill the human mind with information as well. Language is also an advanced talent that involves four sub-skills, namely listening, writing, speaking, and reading skills (Husain, 2015). Utilization of technology has become a very important part of the training process and is out of the category. Technology has been utilized to facilitate and enhance learning. Reading comprehension skills are an interactive process involving the reader, the reading and the context. This skill involves the ability to derive meaning from written texts as stated by Silliman and Wilkinson (2007) "Reading comprehension is generally defined as the ability to acquire meaning from written text". Through the process of reading comprehension, readers gain an understanding of the text they are reading related to new information and vocabulary.

The comprehension skill is the process of capturing the meaning of words or sentences that have been read. This skill is on an order of magnitude higher. Aspects include: understanding simple terms; understand the significance or meaning (the author's intention and the reader's reaction); content evaluation or assessment; as well as flexible reading speed, which is easily adapted to the circumstances. To achieve the desired goal in comprehension skills, the most appropriate activity is reading silently. One aspect of language skills, namely reading skills based on the ability to read, being able to read does not mean automatically reading. According to Juel in Bastino (2007) reading is a process of recognizing words and integrating the meaning of words in sentences and reading structures. Reading is a skill to make an interpretation of the material read. 


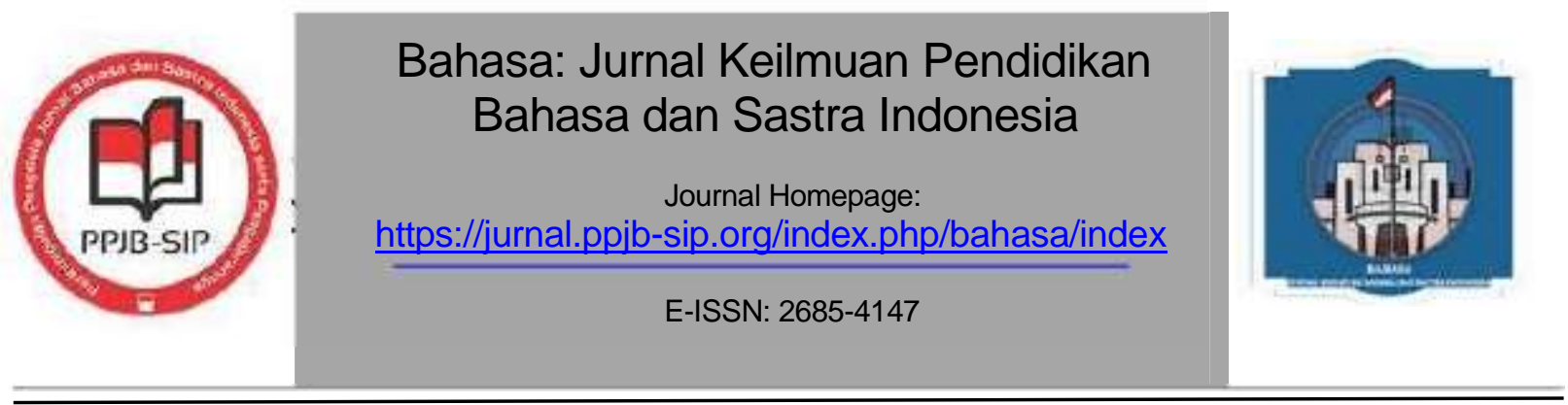

According to Crawley and Mountain, reading is essentially a complex thing that involves many things, not just reciting the text, but also involving visual activities. Reading is a process of translating written symbols (letters) into spoken words, as a process of thinking, reading and reading. Includes word recognition, literal comprehension, interpretation, critical reading and creative comprehension activities. Word recognition can be an activity of reading words using a dictionary. So the reader is a complex or complicated thought process, which involves many things, not just written or spoken because it also involves attitudes, thoughts and experiences to focus attention on each reading.

Hafner and Jolly (2017) state the undersanding is a person's ability to understand, comprehend, to absorb with reason. Comprehension is divided into three categories, namely literal understanding, interpretation, and critical reaction. The goal is that the reader can understand the contents of the reading text. Carlson argues that speed and comprehension have a negligible correlation over difficult reading materials. Carlson found that, at a high level of intelligence, fast readers were the best at reading comprehension. Slow readers often believe that slow readers often believe that fast readers have a lower level of understanding. However, this is actually not the case, because readers are quick to see rows of words as part of a whole sentence or paragraph, not separated to understand the content and meaning, they see the words in the context of the whole sentence, they read quickly and concentrate on reading content.

One of technique that can be used to improve reading skills today is by utilizing artificial abilities. One edge technology used to improve English language skills is understood as artificial intelligence (Ahmadi, 2018). Consistent with The New International Webster's Comprehensive English Dictionary, encyclopedic edition, artificial intelligence deals with computer events that can interact humanely with thought processes such as learning, reasoning, and self-correction. The idea of the machine is that it is often upgraded to consume some abilities that are usually considered human intelligence such as learning, adapting, self-correcting and so on. Before artificial intelligence became popular, students usually used other media to improve their listening skills.

In this study, we tested the correlation between artificial intelligence to provide an opportunity for students or English learners to improve their English reading skills. This aims to clarify about some artificial intelligence mobile applications that will be used for students majoring in English to master reading skills. The term artificial intelligence or AI for short was coined by John McCarthy in the very famous Dartmounth collage workshop, held in the summer of 1956 (Bengko \& Sik Lanyi, 2011). Artificial intelligence belongs to the branch of mathematics presented by which help to uncover intellectual problems as many branches help (Abu Mostafa) 2018.

There are several previous studies that explain the relationship of artificial ability to help improve English language skills. Among others are 1) Kose and Arslan investigated about artificial intelligence that can support e-learning scenarios to ensure a better teaching and learning experience along with educational activities (Kose \& Arslan, 2015). 2) 


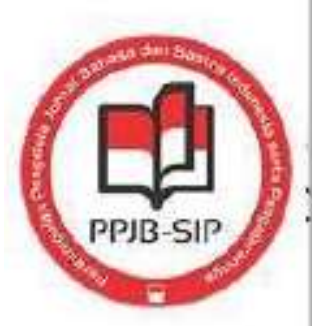

\section{Bahasa: Jurnal Keilmuan Pendidikan Bahasa dan Sastra Indonesia}

Journal Homepage:

https://jurnal.ppib-sip.org/index.php/bahasa/index

E-ISSN: $2685-4147$

Investigating artificial intelligence integrates spoken English practice and writing skills. His research focuses on the use of artificial intelligence in language teaching and learning, especially the Lucy program (Yang, 2017). 3) The application of artificial intelligence that can be used to improve English speaking skills. His article emphasizes the benefits of using an AI application called elsa to improve English language skills (Casey Hynes, 2016). 4) Artificial intelligence such as Google and Grammarly can help people to increase writing. He explained that Google and Grammarly save millions of embarrassing mistakes caused by carelessness (Bernard Marr, 2018).

There are several ways to improve students' English reading skills carried out by teachers. Students are required to recruit in the web course but they will use the mobile app to learn the language. Learning languages through mobile apps can build their learning fun. Some artificial intelligence mobile applications that can improve English reading skills such as Novel Applications, Sports and Podcasts, and Netflix.

McLaughlin and Allen (2007), the principles of reading based on research that most influence reading comprehension are as follows: (1) comprehension is a social constructivist process. (2) literacy balance is a curriculum framework that fosters understanding, (3) professional reading teachers influence student learning, (4) good readers play a strategic role and play an active role in the reading process, (5) reading should occur in context which is meaningful, (6) students find the benefits of reading derived from various texts at various grade levels, (7) vocabulary development and learning affect reading comprehension, (8) inclusion is a key factor in the comprehension process, (9) reading strategies and skills can be taught, and (10) dynamic assessments inform reading comprehension learning.

In language development, Piaget in Cox (1999: p.50) states that "language development" according to him, language development is an aspect of overall cognitive development. Language also affects the cognitive level of students. At this age range students can use language flexibly and articulations begin to sound correctly. Finochiaro in the reading dance is bringing meaning to and getting meaning from printed or written material, picking and understanding the meaning or meaning contained in the reading. It is clear that reading is a process related to language. Therefore, children should be helped to respond or respond to visual signs depicting the same auditory signs they have learned.

\section{METHOD}

In this study, research uses quantitative methods with correlation techniques, according to Sugiyono (2017), correlational research is a type of research with problem characteristics in the form of correlational relationships between two or more variables. In this research, the researcher uses the form of relationship studies with the intention to find out whether there is a relationship between the independent variable and the dependent variable. The form of this research was chosen because it is in accordance with the form of research, namely to determine the level of causal relationship between artificial intelligence possessed by students and the achievement of English reading skills in the $2^{\text {nd }}$ semester of the English education 


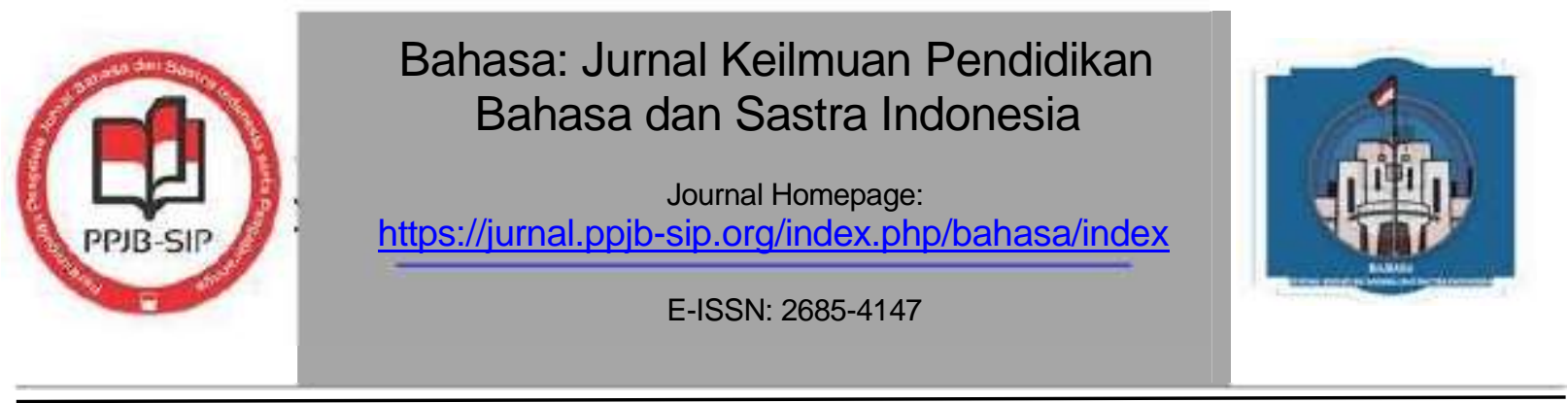

study program at Islamic University of Kalimantan Muhammad Arsyad Al Banjari Banjarmasin.

According to Sugiyono (2011: 117), "Population is a generalization area consisting of: research objects/subjects that have certain qualities and characteristics determined by researchers to be studied and then drawn conclusions." The population in this study is all $2^{\text {nd }}$ semester students in the English Education Study program at Islamic University of Kalimantan Muhammad Arsyad Al Banjari Banjarmasin. Sample of research based on Sugiyono (2015:81), is part of the number and characteristics taken from the population. The sampling technique in this study was all $2^{\text {nd }}$ semester students in the English education study program at Islamic University of Kalimantan Muhammad Arsyad Al Banjari Banjarmasin.

Data collection techniques according to Sugiyono (2017:137) are systematic and standard procedures to obtain the necessary data. The data needed in this study were obtained using data collection methods by: 1) observation (direct observation), namely by direct observation; 2) interviews, which are conducted by the author by dealing directly with the respondents and providing questions related to the issues discussed as needed; and 3) questionnaires, namely by giving or distributing questionnaires to respondents to then be answered and students' final grades.

The data collection tool used for direct observation is an observation sheet. The data collection tool used for direct communication techniques is an interview guide, and the data collection tool used for indirect communication techniques is a questionnaire (questionnaire). According to Sugiyono (2009: 199) questionnaire is a data collection technique that is done by giving a set of questions or written questions to respondents to answer. The data collection tool in the form of a questionnaire (questionnaire) can be used as an objective data collection tool and is able to test research hypotheses, it is necessary to analyze the data collection tool by testing the validity.

To answer the research hypothesis that has been formulated, namely that there is a significant correlation between students' artificial intelligence and the achievement of English reading skills in $2^{\text {nd }}$ semester of the English education study program at Islamic University of Kalimantan Muhammad Arsyad Al Banjari Banjarmasin, the research data in the form of data from questionnaires is processed according to the steps as follows: To answer subproblem 1, the artificial intelligence owned by $2^{\text {nd }}$ semester students (independent variable), whose data form is from questionnaire data, analyzed by the percentage formula according to Ngalim Purwanto (2010:102) as follows:

$$
N P=\frac{R}{S M} \times 100
$$

To answer subproblem 2, namely the achievement of English reading skills in $2^{\text {nd }}$ semester of the English education study program at Islamic University of Kalimantan 


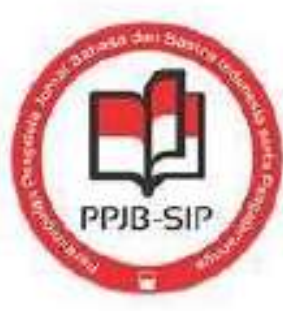

\section{Bahasa: Jurnal Keilmuan Pendidikan Bahasa dan Sastra Indonesia}

Journal Homepage:

https://jurnal.ppjb-sip.org/index.php/bahasa/index

E-ISSN: $2685-4147$

Muhammad Arsyad Al Banjari Banjarmasin (bound variable) whose data form is taken from student learning outcomes, it is analyzed using the percentage formula according to Ngalim Purwanto (2010:102) is as following:

$$
N P=\frac{R}{S M} \times 100
$$

To answer subproblem 3. Because the researcher wants to know whether there is a correlation between the two variables between artificial intelligence possessed by students and the achievement of English reading skills, it is analyzed using the correlation coefficient formula (r) Product-moment according to Suharsimi Arikunto (2006:274):

$$
r x y=\frac{n \sum x y-\left(\sum x\right)\left(\sum y\right)}{\left.\sqrt{\left\{n \sum x^{2}\right.}-\left(\sum x^{2}\right)\right\}\left\{n \sum y^{2}-\left(\sum y^{2}\right\}\right.}
$$

To find out how big the level of relationship between the independent variable (x), namely students' artificial intelligence of $2^{\text {nd }}$ semester and the dependent variable (y), namely the achievement of students' English reading skills, according to the applicable provisions according to Sugiyono (2011: 257) in the following table:

Table 1. The Level of Correlation

\begin{tabular}{cc}
\hline Range & Categories \\
\hline $0,00-0,199$ & Very Low \\
$0,20-0,399$ & Low \\
$0,40-0,599$ & Middle \\
$0,60-0,799$ & Good \\
$0,80-1,000$ & Very God \\
\hline
\end{tabular}

The criteria for testing the hypothesis according to Awalludin (2009:3.16) are with a significant level of $1 \%$ or $5 \%$ and degrees of freedom $(\mathrm{df})=\mathrm{N}-2$, if (1) rxy count $>$ rxy table then $\mathrm{Ha}$ is accepted and Ho is rejected, (2 ) rxy count < rxy table then Ha is rejected and Ho is accepted.

\section{RESULT AND DISCUSSION}

This study aims to describe the correlation between students' artificial intelligence with the achievement of English reading skills of second semester students in the English Education study program at Islamic University of Kalimantan Muhammad Arsyad Al Banjari Banjarmasin. The samples in this study were 30 people. From the sample, the data obtained from filling out artificial intelligence questionnaires owned by students with the results of the 


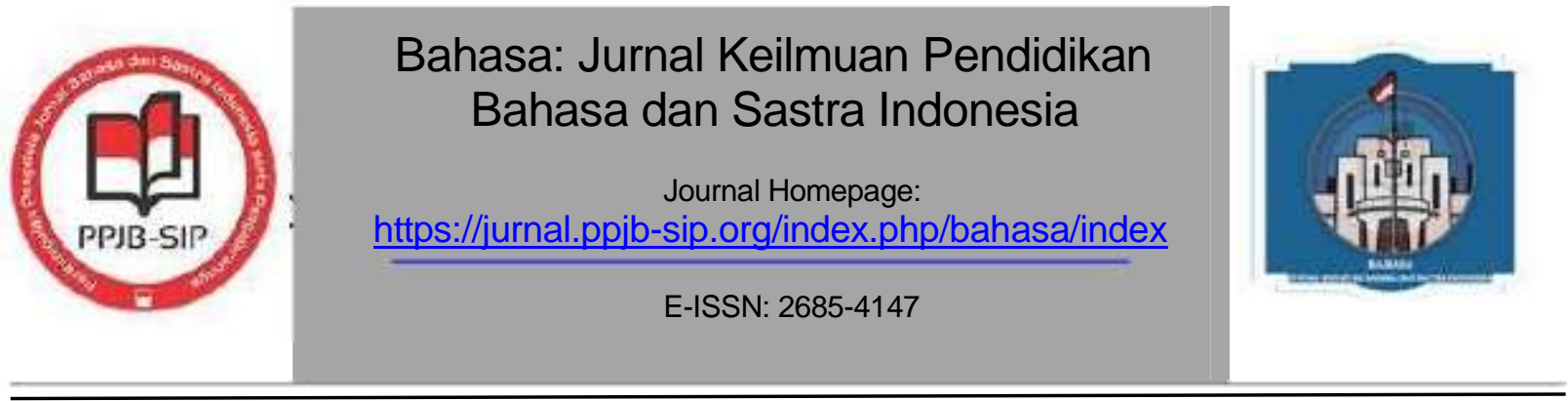

midterm exam (UTS) which has been distributed into a distribution table so that it can be processed using statistical calculations and then the value of the product moment correlation coefficient (r) is calculated. The results of the calculation of correlation between students' artificial intelligence with the achievement of English reading skills that have been processed can be seen in the following table:

Table 2. Correlation Coefficients and Data Processing of Artificial Intelligence Questionnaires and Learning Outcomes of Students' English Reading Skills

\begin{tabular}{lcccc}
\hline \multirow{2}{*}{ Variable } & \multicolumn{2}{c}{ Score } & Percentage & Categories \\
\cline { 2 - 4 } & Raw & $\begin{array}{c}\text { Ideal } \\
\text { Maximum }\end{array}$ & Value & Good \\
\hline $\begin{array}{l}\text { Artificial Intelligence } \\
\text { (Independent Variable) }\end{array}$ & 2,99 & 3,72 & $80.32 \%$ & Good \\
\hline $\begin{array}{l}\text { Reading Skills } \\
\text { (Dependent Variable) }\end{array}$ & 2,91 & 3,72 & $78.30 \%$ & Good \\
\hline $\begin{array}{l}\text { Correlation Coefficients } \\
\text { of Product Moment }\end{array}$ & & 0,67 & & \\
\hline
\end{tabular}

From the table above, it can be seen that: (1) The the artificial intelligence owned by $2^{\text {nd }}$ semester students in the English Education study program at Islamic University of Kalimantan Muhammad Arsyad Al Banjari Banjarmasin is a raw score of 2,99 and the ideal maximum score of 3,72 until after being calculated using the percentage formula (NP) a percentage value of $80.32 \%$ was obtained. and included in the "Good" category, (2) The the achievement of English reading skills in $2^{\text {nd }}$ semester of the English education study program at Islamic University of Kalimantan Muhammad Arsyad Al Banjari Banjarmasin obtained a raw score of 2,91 and an ideal maximum score of 3,72 until after being calculated using the Percentage formula (NP) the percentage value was $78.30 \%$ and is included in the "Good" category.

Based on the results of the calculation of the percentage value (NP) regarding a correlation between the two variables between students' artificial intelligence and the achievement of English reading skills in $2^{\text {nd }}$ semester of English education study program at Islamic University of Kalimantan Muhammad Arsyad Al Banjari Banjarmasin, then Ha is accepted, that is, there is a significant correlation between students' artificial intelligence and the achievement of English reading skills in $2^{\text {nd }}$ semester of English education study program at Islamic University of Kalimantan Muhammad Arsyad Al Banjari Banjarmasin. The students' reading interest is "good" then the students' motivation in learning also shows the "good" category. 


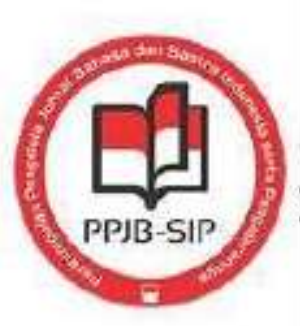

\section{Bahasa: Jurnal Keilmuan Pendidikan Bahasa dan Sastra Indonesia}

Journal Homepage:

https://jurnal.ppib-sip.org/index.php/bahasa/index

E-ISSN: $2685-4147$

\section{CONCLUSION}

After doing the research and getting the result the researcher can conclude that there is significant correlation between students' artificial intelligent and the achievement of English reading skills in $2^{\text {nd }}$ semester of English education study program at Islamic University of Kalimantan Muhammad Arsyad Al Banjari Banjarmasin. It show by the result of the research. The result (0.67) belongs a good good correlation.

\section{REFERENCES}

Casey Hynes. (2016, August). The App Using Artificial Intelligence To Improve English Speaking Skills. Forbes. https://www.forbes.com/sites/chynes/2016/08/30/the-appusing-artificial-intelligence-to-improve-english-speaking-skills/?sh=4a57076f1c82.

Castillo-Montoya, M. (2016). Preparing for interview research: The interview protocol refinement framework. Qualitative Report, 21 (5), 811-831. https://doi.org/10.46743/2160-3715/2016.2337.

Chassignol, M., Khoroshavin, A., Klimova, A., \& Bilyatdinova, A. (2018). Artificial Intelligence trends in education: A narrative overview. Procedia Computer Science, 136, 16-24. https://doi.org/10.1016/j.procs.2018.08.233.

Herlina. (2016). Meningkatkan Keterampilan Membaca Pemahaman Bahasa Inggris Melalui Metode SQ4R. Jurnal Ilmiah VISI PPTK PAUDNI, Vol. 11 (1). https://doi.org/10.21009/JIV.1101.4

Lutfiansyah. (2016). Penggunaan Aplikasi Mobile Pembelajaran Bahasa Inggris Android pada Pembelajaran Bahasa Inggris (Pengamatan Terhadap Sumber Belajar Berbasis Android Melalui Media Mobile Smartphone). Eduscience, 2 (1). https://ejurnal.esaunggul.ac.id/index.php/EDU/article/view/1545.

Marr, Bernard. (2018). The Key Definitions Of Artificial Intelligence (AI) That Explain Its Importance. 2018/04/02, 1.

Somadayo, Samsu. (2011). Strategi dan Teknik Pembelajaran Membaca. Yogyakarta: Graha Ilmu.

Sugiyono. (2017). Metode Penelitian Kuantitatif, Kualitatif dan R \& D. Bandung : Alfabeta.

Suryana Irfan, Asrianto, \& Didik Murwantono. (2020). Artificial Intelligence to Master English Listening Skills For Non-English Major Students. JOLLT Journal of Language and Language Teaching, Vol. $8 \quad$ (1). DOI: https://doi.org/10.33394/jollt.v8i1.2221.

Yoestara M., \& Putri Z. (2019). PODCAST: An Alternative Way To Improve EFL Students' Listening and Speaking Performance. Englisia Journal, Vol. 6 (1), 15. https://doi.org/10.22373/ej.v6il.3805. 